\title{
Medieval Seaports of the Atlantic Coast of Spain
}

\section{Jesús Angel Solórzano Telechea ${ }^{1}$}

\section{Introduction: Historiography of Seaports in Atlantic Spain}

Scholarly interest in Spain's Atlantic seaports during the Middle Ages has grown steadily since the 1970s. Although this phenomenon has various causes, two are doubtless the modern-day concern about the current and future prospects for urban areas and a belief that a fuller knowledge of the past can improve our approach to contemporary issues. That being said, it should come as no surprise that the historiography has also been influenced by societal conditions in Spain during the 1950s and 1960s. Thus, the warping of the history of the Kingdom of Castile for political purposes during the Franco regime hampered our understanding of the region's past, including its medieval history. ${ }^{2}$

Happily, the end of the Franco era led to a flowering of intellectual inquiry, which in the case of port history was sparked by the publication of collections of documents preserved in municipal archives. New work based in part on this material during the late 1970s and early 1980s began a redefinition of medieval Castilian history in general and port history in particular. The publication of additional archival material in the early 1990s promoted a new outburst of scholarly inquiry distinguished by new approaches to urban history. ${ }^{3}$

${ }^{1}$ This work is based in the Department of Medieval History at the University of Cantabria as part of a larger research project entitled "Ports et structuration de l'espace dans le Golfe de Gascogne à la fin du Moyen Age" (J.E. 2433), which began in 2004 in the Department of History at the University of La Rochelle. I am grateful to the Journal's two anonymous referees for valuable comments.

${ }^{2}$ Juan A. Bonachía Hernando (ed.), La ciudad medieval: Aspectos de la vida urbana en la Castilla Bajomedieval (Valladolid, 1996); and María Asenjo González, "La ciudad medieval castellana: Panorama historiográfico," Hispania, L, No. 2 (1990), 793-808.

${ }^{3}$ Fernando López Alsina, Introducción al fenómeno urbano medieval gallego, a través de tres ejemplos: Mondoñedo, Vivero y Ribadeo (Santiago de Compostela, 1976); Beatriz Arizaga Bolumburu, El nacimiento de las villas guipuzcoanas en los siglos XIII y XIV: Morfología y funciones urbanas (San Sebastián, 1978); Arízaga Bo-

International Journal of Maritime History, XXI, No. 1 (June 2009), 81-100. 
Some aspects began to be studied for the first time, such as kinship; political systems; municipal government; violence and social unrest; the city as a centre of power; the relationship between city councils and other institutions; the social distribution of power; and the social organization of urban space. Interest in urban matters was accompanied by studies of the relationship between the urban and rural worlds and a recognition of the existence of a "dual economy." This reflected work elsewhere, especially in France and Italy; in the Spanish context, the earliest foci were the Basque Country and Galicia.

The 1970s and 1980s also featured a number of gatherings of urban medievalists, notably "Forms of Settlement in Biscay" (1975) and "The Hispanic City" (1981), as well as congresses on city charters, including San Sebastián (1980), Santander (1987) and Laredo (2000). Most focused attention on social, political, cultural and economic activities in urban ports. ${ }^{4}$ In the 1990s, the opening of the Royal Chancellery of Valladolid led to new monographs that reflected trends in European historiography. But only in the present century has the Cantabrian coast become a focus of medieval urban studies. ${ }^{5}$

lumburu, "El abastecimiento de las villas vizcaínas medievales: política comercial de las villas respecto al entorno y a su interior," in Emilio Sáez, et al. (eds.), La ciudad hispánica durante los siglos XIII al XVI (3 vols., Madrid, 1985), I, 293-316; Elisa Ferreira Priegue, Galicia en el comercio marítimo medieval (La Coruña, 1988); José I. Ruiz de la Peña, "Poblamientos y cartas pueblas de Alfonso X y Sancho IV en Galicia," in Homenaje a don José María Lacarra de Miguel en su jubilación del profesorado: estudios medievales (3 vols., Zaragoza, 1977), III, 27-60; Ruiz de la Peña, Las "polas" asturianas en la Edad Media: Estudio y Diplomatario (Oviedo, 1981); Ermelindo Portela Silva, "Sistema feudal y proceso de urbanización: las ciudades de Galicia ante la crisis bajomedieval," Jubilatio, I (1987), 83-93; and José García Oro, Galicia en los siglos XIV y XV: Galicia Urbana (2 vols., Pontevedra, 1987), II.

${ }^{4}$ Las formas del poblamiento en el Señorio de Vizcaya durante la Edad Media (Bilbao, 1978); Sáez, et al. (eds.), La ciudad hispánica, I; El fuero de San Sebastián y su época (San Sebastián, 1981); El fuero de Santander y su época (Santander, 1989); and Juan Baró Pazos (ed.), El Fuero de Laredo en el Octavo Centenario de su Concesión (Santander, 2001).

${ }^{5}$ Examples include Beatriz Arízaga Bolumburu, Urbanística medieval (Guipúzcoa) (San Sebastián, 1990); Arízaga Bolumburu, "El litoral vasco peninsular en la época preurbana y el nacimiento de la villa de San Sebastián," Lurralde, XIII (1990), 227-312; Dolores Barral Rivadulla, La Coruña en los siglos XIII al XV (La Coruña, 1997); Soledad Tena García, La sociedad urbana en la Guipúzcoa costera medieval: San Sebastián, Rentería y Fuenterrabía (1200-1500) (San Sebastián, 1997); José A. Achón Insausti, $A$ voz de concejo. Linaje y corporación urbana en la constitución de la Provincia de Guipúzcoa: Los Báñez y Mondragón, siglos XIII-XVI (San Sebastián, 1995); and Iñaki Bazán Díaz, Delincuencia y criminalidad en el País Vasco en la transición de la Edad Media a la Moderna (Vitoria, 1995). For work on Cantabria, see Jesús A. Solórzano Telechea and Beatriz Arízaga Bolumburu (eds.), El fenómeno ur- 
The historiography of the Atlantic ports of medieval Spain has been dominated by urban and maritime history, with an emphasis in the latter on mercantile activities. This has been distinguished by an analysis of individual cities; only Jean Gautier Dalché has considered the broader urban world of Atlantic Spain. ${ }^{6}$ The focus has been on four main topics: town planning, the granting of charters and privileges, commercial relations and territorial conflict. Yet some important topics remain unexplored, notably the emergence of urban networks within northern Atlantic Spain and the still broader question of the relationship between this region and the rest of Western Europe.

\section{Seaports on the Northern Coast of Atlantic Spain}

Historical studies of urban networks traditionally have focused on the grouping of towns and cities into regional hierarchies and their role on the national stage. At its most basic level, a network comprises three elements: people, communities and institutions. How a network functions is determined by the ties that unite these elements and by their effectiveness. ${ }^{7}$ Such concepts can be applied to medieval as well as modern studies. Here, we will also consider such factors as geography, communications, infrastructure, government policies and economic relationships. Above all, a network implies the existence of relationships based on the flow of people, ideas, innovations and goods. Accordingly, we will first examine the relationships among the towns. ${ }^{8}$

bano medieval entre el Cantábrico y el Duero (Santander, 2002); and Arízaga Bolumburu and Solórzano Telechea (eds.), Ciudades y villas portuarias del Attántico en la Edad Media: Nájera, Encuentros Internacionales del Medievo 2004 (Logroño, 2005).

${ }^{6}$ Jean Gautier-Dalché, Historia Urbana de León y Castilla (siglos IX al XIII) (Madrid, 1979).

${ }^{7}$ Damien Coulon, "Introduction," in Coulon, et al. (eds.), Espaces et réseaux en Méditerranée Vie-XVIe siècle (Paris, 2007), 9.

${ }^{8}$ On Atlantic urban networks, see Wim Blockmans, "Des systèmes urbains: pourquoi?" Le réseau urbain en Belgique dans une perspective historique (1350-1850): Une approche statistique et dynamique (Brussels, 1992), 243-248; Blockmans and Lex Heerma van Voss, "Urban Networks and Emerging States in the North Sea and Baltic Areas: A Maritime Culture?" in Juliette Roding and Lex Heerma van Voss (eds.), The North Sea 1550-1800: A Cultural Unity (Hilversum, 1996), 10-20; Michel Mollat du Jourdin, Europa y el Mar (Barcelona, 1993); Peter Stabel, Dwarfs among Giants: The Flemish Urban Network in the Late Middle Ages (Louvain, 1997); Ports maritimes et ports fluviaux au Moyen Age (París, 2005); Michel Bochaca and Jean Luc Sarrazin (eds.), Ports et littoraux de l'Europe Atlantique: Transformations naturelles et aménagements humains (XIVe-XVle siècles) (Rennes, 2005); and Coulon, et al. (eds.), Espaces et réseaux en Meditérranée. 


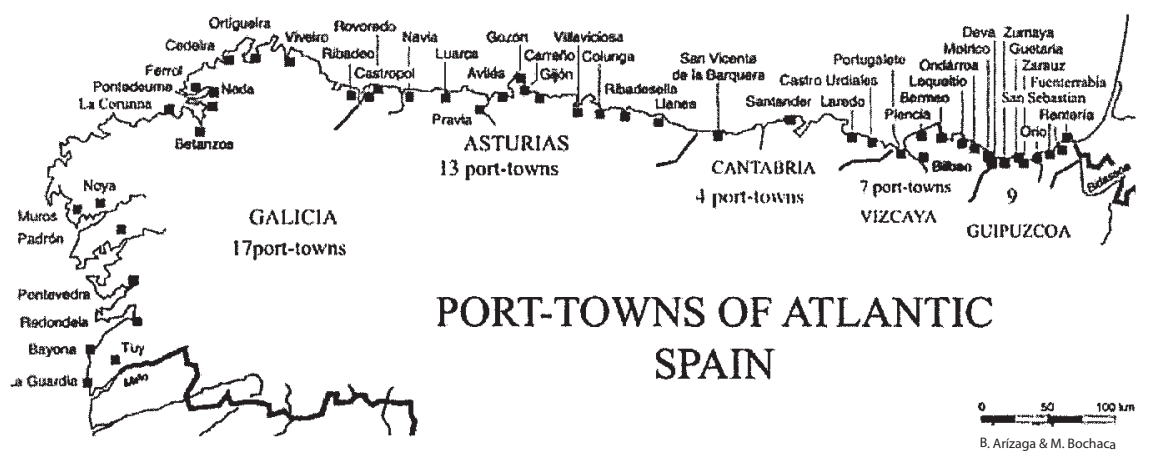

Figure 1: Seaports of Medieval Atlantic Spain

Source: Courtesy of the author.

In the Middle Ages, Spain's Atlantic seaports were part of a region known as the Marisma Costera de España, extending from Fuenterrabia in Guipuzcoa, near the French border, all the way to Tuy, near Portugal, thus taking in the entire Cantabrian coast. This stretch of coastline, approximately 1300 kilometres in length, was also the maritime frontier of the Kingdom of Castile. ${ }^{2}$ It contains two distinct geo-morphological regions: the Cantabrian coast itself, steep and buffeted by stormy seas, and taking in the Basque Country; and the Galician coast from Cantabria to the Portuguese border, which is more irregular and contains several estuaries that form natural ports (Ferrol, Corunna, Muros, Arosa, Pontevedra and Vigo). ${ }^{10}$ The essential elements of these seaports can be summarized as follows: sandy beaches to facilitate loading, unloading, and related activities; promontories offering protection from the wind and conferring defensive advantages in wartime; river mouths and smaller watercourses providing a water supply and serving as a means of communication with the interior; and proximities to sea lanes. ${ }^{11}$ Politically, the region contained five territorial entities (see figure 1). On all parts of the coast,

'Jesús A. Solórzano Telechea, Patrimonio documental de Santander en los Archivos de Cantabria: Documentación medieval (Santander, 1998), 80 and 255. At the end of the Middles Ages, the town of Santander reported that "this town is the frontier of Castile with France and Britain."

91-284.

${ }^{10}$ Javier Díez González, Guía fisica de España: Las Costas (Madrid, 1996),

${ }^{11}$ For the Mediterranean area, see Silvia Orvietani Bush, Medieval Mediterranean Ports: The Catalan and Tuscan Coast, 110 to 1235 (Leiden, 2001). 
the interplay between geo-morphology and politics exercised a fundamental role in determining the transformation of a port into a seaport. ${ }^{12}$

Castile's Atlantic seaports were not isolated enclaves but comprised an urban network whose relationships with the cities of the interior evolved over time. After the conquest of Seville in 1248, the seaports were a fulcrum for relations between the northern and southern sections of the Iberian Peninsula. They began to play a more important role as centres of commercial exchange and the redistribution of goods. But their consolidation into a network was a lengthy process heavily influenced by the monarchy. In short, economics, power, and space were interconnected. ${ }^{13}$

The seaports of Atlantic Spain were born in the second half of the twelfth century, although most existed as small portii or monasteria since at least the mid-tenth century. ${ }^{14}$ Recent archaeological work suggests that some had even earlier beginnings than indicated by printed records. ${ }^{15}$ Until the twelfth century, royal authority was weak due to the deep-rooted power of feudal lords, particularly in the monastic and episcopal domains. To expand

${ }^{12}$ María L. Ríos Rodríguez, "Los recursos físicos: mundo rural, pesca y actividad industrial," in Vizcaya en la Edad Media: Evolución demográfica, económica y social de la comunidad vizcaína medieval (San Sebastián, 1985), 9-168.

${ }^{13}$ Amélia Aguiar Andrade, "A estratégia régia em relação aos portos marítimos no portugal medieval: o caso da fachada atlântica," in Arízaga Bolumburu and Solórzano Telechea (eds.), Ciudades y villas portuarias, 57-90; and Denis Menjot, "La ville frontière: un modèle original d'urbanisation?" in Les villes frontière Moyen ÂgeÉpoque Moderne (Strasbourg, 1996), 6. On the creation of networks, see Tom Scott and Bob Scribner, "Urban Networks," in Scribner (ed.), Germany: A New Social and Economic History. Vol. I: 1450-1630 (London, 1996), 113-143. On the question of space in the creation of urbanity, see Martha C. Howell, "The Spaces of Late Medieval Urbanity," in Marc Boone and Peter Stabel (eds.), Shaping Urban Identity in Late Medieval Europe (Leuven, 2000), 3-24.

${ }^{14}$ Elisa Ferreira Priegue, "L'incorporation du Nord-Ouest ibérique à la vie économique du golfe de Gascogne," in L'aventure maritime, du golfe de Gascogne à Terre-Neuve (Paris, 1995), 331-340.

${ }^{15}$ José A. Gutiérrez González, "Sobre la transición del sistema antiguo al feudal: una revisión arqueológica del Altomedievo hispano," Territorio, sociedad y poder, No. 1 (2006), 53-78; Excavaciones Arqueológicos en Asturias, 1995-1998 (Oviedo, 1999); José L. Solaun Bustinza, La cerámica medieval en el País Vasco (siglos VIIIXIII): sistematización, evolución y distribución de la producción (Vitoria, 2005); and Belén Bengoetxea Rementería and Juan A. Quirós Castillo, "Las Villas vascas antes de las villas: La perspectiva arqueológica obre la génesis de las villas en el País Vasco," El Espacio Urbano en la Europa Medieval. Nájera. Encuentros internacionales del Medievo 2005 (Logroño, 2006), 147-165. 
their influence along the Atlantic coast, the kings of Castile endeavoured to create new towns by granting charters and economic privileges designed to promote exports while protecting domestic trade. In 1255, for example, Alfonso $\mathrm{X}$ gave Corunna an absolute monopoly over the Galician salt trade and export tax revenues from Santander and Castro Urdiales. The kings pursued a strategy of control on the Cantabrian coast for good reason: it was the natural border with France and was therefore certain to play a role in the exchange of goods. Indeed, the seaports of the Galician and Cantabrian coasts were pivotal in trade with France, England and Northern Europe in the late Middle Ages. ${ }^{16}$

\section{Creating an Urban Network on the Castilian Coast: Kings and Merchants}

Urban development on Spain's Atlantic coast was initiated in the twelfth century to achieve royal goals in the area. ${ }^{17}$ Seaports emerged relatively late compared with other parts of Europe and did not really start until after the death of Alfonso VII in 1157 and the former Kingdom of Castile and León was split in two. Admittedly, Alfonso VII created royal seaports in Galicia and Asturias using royal charters, but it was not until the reigns of Fernando II and Alfonso IX that we begin to see intensive urban development in the region.

Royal foundation charters (Fueros) were the monarchs' chief means of asserting and extending control along the coast, altering the regional balance

${ }^{16}$ César González Mínguez, "La urbanización del litoral del Norte de España (siglos XII- XIV)," in III Semana de Estudios Medievales de Nájera (Logroño, 1993), 43-62; Ferreira Priegue, Galicia, 84; Solórzano Telechea, Patrimonio documental de Santander, 17; Manuel González Jiménez, "Frontier and Settlement in the Kingdom of Castile (1085-1350)," in Robert Bartlett and Angus Mackay (eds.), Medieval Frontier Societies (Oxford, 1989), 70-73; Wendy R. Childs, Anglo-Castilian Trade in the Later Middles Ages (Manchester, 1978); Elisa Ferreira Priegue, “Castilla: La génesis de una potencia marítima en Occidente," Itinerarios medievales e identidad hispana, XXVII Semana de Estudios Medievales de Estella (Pamplona, 2001), 23-45; Beatriz Arízaga Bolumburu, "Las actividades económicas de las villas marítimas del Norte Peninsular," in XXIX Semana de Estudios Medievales de Estella (Pamplona, 2003), 195-242; Jean Finot, Étude historique sur les relations commerciales entre la Flandre et l'Espagne au Moyen Age (Paris, 1894); Francisco Morales Belda, La hermandad de las Marismas (Barcelona, 1973); Castilla y Europa: comercio y mercaderes en los siglos XIV, XV y $X V I$ (Burgos, 1995); and Eduardo Inclán Gil, "El dinero de la mar: el comercio de la costa vasca con Europa en los siglos XIV al XVI," in Ernesto García Fernández (ed.), Bilbao, Vitoria y San Sebastián: espacios para mercaderes, clérigos y gobernantes en el Medievo y la modernidad (Bilbao, 2005), 16-78.

${ }^{17} J o s e ́$ Ignacio Ruiz de la Peña Solar, "Desarrollo urbano y reacción señorial: monasterios 'versus' concejos en el Noroeste peninsular (siglos XII-XIII)," in El monacato en los reinos de León y Castilla (siglos VII-XIII) X Congreso de Estudios Medievales (2005) (León, 2007), 329-360. 
of power in the process. ${ }^{18}$ In Galicia, Fernando II (1157-1188) and Alfonso IX (1188-1230) sought to create royal ports to supplant the economic influence of the bishopric of St. James of Compostela and of the bishopric's own port town, Padrón. Although this initiative bore fruit with Noya (1168) and Pontevedra (1169), these soon fell under the bishopric's influence. But Alfonso IX continued the work of his predecessors by founding Ribadeo (1182), Vivero (c. 1190), Laguardia (c. 1200), Bayonne (1201), Betanzos (1219) and especially Corunna (1208), which because of its unique mercantile dynamism became the most important royal port in Galicia. ${ }^{19}$ After the reunion of Castile and León in 1230, Alfonso X used the royal privilege of annual duty-free markets to create ports in Galicia, most notably Ortigueira (1255).

In 1268 , Alfonso $\mathrm{X}$ began a campaign to establish royal authority, starting with the establishment of the port of Llanes. Next, he issued charters to Gijon (1270), Luarca, Roboredo, Villaviciosa, Ribadesella, Candás and Luanco. These efforts aroused predictable opposition from the nobility and church officials, and in some cases the kings had to abandon their fledgling ports to these deeply entrenched interests. Pontevedra, for example, was founded by Fernando II in 1169 but was yielded to the bishop of St. James in 1180. A classic example of conflict between the competing jurisdictions occurred in the estuary of Ribadeo, which formed a natural border between the bishoprics of Oviedo and Mondoñedo. The port of Ribadeo dated from 1182, but in 1282 Alfonso $X$ founded Roboredo on the opposite shore, initiating an intense rivalry between the ports. Matters were further complicated after the bishop of Oviedo founded a third port town, Castropol, in the same area. The royal town eventually vanished. ${ }^{20}$

Between 1157 and 1200 , under the necessity of finding outlets for the produce of the interior, Alfonso VIII launched an ambitious program to create seaports in the central part of the Cantabrian coast. Three seaports resulted

${ }^{18}$ See the articles by Elisa Ferreira Priegue, Ignacio Ruiz de la Peña, Jesús Solórzano, José R. Díaz de Durana and Lorena Fernández in Solórzano Telechea and Arízaga Bolumburu (eds.), El fenómeno urbano medieval. See also José I. Ruiz de la Peña, "El nacimiento de las villas costeras cántabro-atlánticas y su instrumentación jurídica (siglos XII-XIII)," in Baró Pazos (ed.), El Fuero de Laredo, 156.

${ }^{19}$ García Oro, Galicia, II; Barral Rivadulla, La Coruña; Ruiz de la Peña, "Poblamientos," 27-60; and José Armas Castro, Pontevedra en los siglos XII a XV: Configuración y desarrollo de una villa marinera en la Galicia medieval (Pontevedra, 1992).

${ }^{20}$ Ruiz de la Peña, Las "polas" asturianas; and Beatriz Arízaga Bolumburu, "Conflictividad por la jurisdicción marítima y fluvial en el Cantábrico en la Edad Media," in Arízaga Bolumburu and Solórzano Telechea (eds.), Ciudades y villas portuarias, $17-56$. 
from this initiative: Castro Urdiales (1163), Santander (1187) and Laredo (1200); a fourth, San Vicente de la Barquera, was added in $1210 .^{21}$ With the recovery of the Basque coast in 1200, Alfonso VIII granted charters for Fuenterrabía (1203), Guetaria (1209) and Motrico (1209). ${ }^{22}$ Port development along the coast was completed in the fourteenth century with the founding of four other ports: Rentería (1320), Deva (1343), Zumaya (1347) and Orio (1379). The noble family of Haro laid the urban foundations of the Biscayan coast: Bermeo (1236), Plencia (1299), Bilbao (1300), Portugalete (1322), Lequeitio (1325) and Ondárroa (1327) ${ }^{23}$ By means of charters that imitated those issued by the monarchs, the Biscayan lords gave the promoters of these seaports economic privileges such as duty-free markets and free trade. ${ }^{24}$

The seaports were material and logistical bases for commercial and personal connections not only with each other but also with their regional hinterlands and international markets. As the kings pursued a policy of consolidation, merchants sought to influence consumption and production - and to make greater profits - by expanding trade. In Castile, as elsewhere, the resulting domestic and international trade routes were the framework that grouped the ports into networks. ${ }^{25}$ From the twelfth century, the seaports began to forge commercial and fishing links with the main ports of Atlantic Europe, especially La Rochelle and those in southern England. ${ }^{26}$

The fruits of seaport development were distributed unevenly, chiefly because ports with closer ties to royalty received preferential treatment. For example, during the thirteenth century the kings bestowed trading privileges on

${ }^{21}$ Jesús A. Solórzano Telechea, Santander en la Edad Media: patrimonio, parentesco y poder (Santander, 2002); and Solórzano Telechea, "La fundación y promoción de las 'villas nuevas' en litoral Atlántico del Norte peninsular durante el reinado de Alfonso X," in El mundo urbano en la Castilla del siglo XIII: 750 Aniversario de la Fundación de Ciudad Real (Ciudad Real, 2006), 315-328.

${ }^{22}$ Ana Basabe Martín, "Estudio lingüístico del fuero de San Sebastián," in $E l$ fuero de San Sebastián, 27-68; and María R. Ayerbe Iríbar, "Los fueros vizcaínos y guipuzcoanos en el contexto del derecho medieval castellano," in Baró Pazos (ed.), El Fuero de Laredo, 551-586.

${ }^{23}$ Arízaga Bolumburu, El nacimiento; Arízaga Bolumburu, "El litoral vasco;" and Arízaga Bolumburu, Urbanistica medieval.

${ }^{24}$ Vizcaya en la Edad Media, I, 162-166.

${ }^{25}$ Blockmans and van Voss, "Urban Networks," 10-20.

${ }^{26}$ Beatriz Arízaga Bolumburu, "La actividad comercial del País Vasco en la Edad Media," in Congreso de Historia de Euskal Herria (San Sebastián, 1988), II, 299; and Ruiz de la Peña, "El nacimiento," 156. 
Santander because of the influence of its abbots, who had family connections to the royal family and members of the court. ${ }^{27}$ Ultimately, with the exception of Avilés, this weakened commercial development along the Asturian shore while fostering it in the Cantabrian and Basque ports, whose merchants had strong ties with counterparts elsewhere in Castile, especially in Burgos. ${ }^{28}$ There were, in effect, two maritime regions: the eastern seaports from Santander to Fuenterrabía, and the western ones from San Vicente de la Barquera to Bayona. The favoured status of the eastern ports was further strengthened by their service to the Castilian crown; they played a key role in the conquest of Seville and in the Hundred Years' War, when the kings of Castile were allied with France, enabling the French to use Cantabrian galleys to devastating effect in raids on coastal Gascony. ${ }^{29}$ By the end of the fourteenth century, royal ships were built in Santander's dockyards (Atarazanas) ${ }^{30}$

The Muslim geographer al-Idrisi's description of the Bay of Biscay as "the sea of the English" strongly suggests English contact with coastal Castile by the early twelfth century. ${ }^{31}$ It is certain that by the early thirteenth century merchants from Castile's eastern seaports were beginning to develop commercial links with the main ports of Atlantic Europe. Like the development of the

${ }^{27}$ Arízaga Bolumburu, "Las actividades económicas," 229-231; and Solórzano Telechea, Santander en la Edad Media.

${ }^{28}$ Luis Suárez Fernández, Navegación y comercio en el Golfo de Vizcaya (Madrid, 1957); Betsabé Caunedo del Potro, Mercaderes castellanos en el Golfo de Vizcaya, 1475-1492 (Madrid, 1983); José I. Ruiz de la Peña, El comercio ovetense en la Edad Media (Oviedo, 1990); Juan Uría Ríu, "Oviedo y Avilés en el comercio atlántico de la Edad Media," Boletín del Instituto de Estudios asturianos, No. 62 (1964), 199-250; Constance Jones Mathers, "Family Partnerships and International Trade in Early Modern Europe: Merchants from Burgos in England and France, 1470-1570," Business History Review, LXII, No. 3 (1988), 367-397; and Michel Bochaca, "Le commerce de Bordeaux dans la seconde moitié du XVe siècle: du marasme à la reprise des affaires," in Mickaël Augeron and Dominique Guillemet (eds.), Champlain ou les portes du Nouveau-Monde: Cinq siècles d'échanges entre le Centre-Ouest français et l'Amérique du Nord XVIe-XXe siècles (La Crèche, 2004), 42-46.

${ }^{29}$ José Luís Casado Soto (ed.), Santander y Cantabria en la conquista de Sevilla (Santander, 1998), 25; and Susan Rose, Medieval Ships and Warfare (Aldershot, 2008), 73.

${ }^{30}$ Lorena Fernández González, Archivo de la catedral de Santander: Documentación medieval (Santander, 1994), doc. 145.

${ }^{31}$ Pamela Nightingale, Trade, Money, and Power in Medieval England (Aldershot, 2007), 129; and José García Mercadal, Viajes de extranjeros por España y Portugal, Vol. 1 (Salamanca, 1999), 196. 
seaports, the evolution of international contacts was profoundly influenced by royal politics. From the mid-thirteenth century to the mid-fourteenth, the seaports availed equally of French and English markets; thanks to the Hundred Years' War, they also made inroads into the Flemish market. ${ }^{32}$ From 1350 to 1475, the kings of Castile opted to support their French counterparts, although significantly this did not stop merchants in the Castilian seaports from trading with English-controlled ports in Gascony, even in wartime. ${ }^{33}$

Trade with France, England and Flanders was well established by the thirteenth century and with Ireland by the fourteenth. In 1224, eight ships laden with goods arrived at the port of La Rochelle. ${ }^{34}$ In 1237 , the merchants of San Sebastián received safe conduct to trade with the English Cinque Ports. Commercial links are better documented after Leonore of Castile's marriage with Edward I and the Anglo-Castilian agreement of 1254. In 1260, Castilian merchants resided in Southampton; in 1385, forty-two percent of ships arriving in the port of London belonged to Castilian merchants. By the end of the fifteenth century, a total of 480 Spanish merchants were living in Bristol, London, Southampton and Sandwich. England's main export to Castile was cloth, followed by grain, tin, lead, feathers, fish, gravestones, sculptural altarpieces, jewellery and books; from Castile came wine, spices, olive oil, leathers, silk, horses, dyes and wool oil. Most of these goods were carried by Castilian sailors in the service of merchants belonging to Castile's eastern seaports and the interior cities of Vitoria and Burgos. ${ }^{35}$ Spanish vessels also carried English goods to France, Gascony, Flanders and even Italy. ${ }^{36}$

${ }^{32}$ Although Spanish-Irish trade was conducted in the fourteenth century, more regular exchanges occurred after the mid-fifteenth century. See Timothy O'Neill, Merchants and Mariners in Medieval Ireland (Dublin, 1987), 85-90 and 122-129.

${ }^{33}$ Thomas Rymer, Foedera, convenciones, literae et cuiuscunque generis acta publica inter reges Angliae et alios quosvis imperatores, reges, pontifices, principes vel communitates (10 vols., The Hague, 1737; reprint, Farnborough, 1967), VI, 29; and Solórzano Telechea, Patrimonio documental de Santander, 18-22.

${ }^{34}$ Mathias Tranchant, Le commerce maritime de La Rochelle à la fin du Moyen Age (Rennes, 2003).

${ }^{35}$ Caunedo del Potro, Mercaderes castellanos; Carlos Estepa Díez, et al., Burgos en la Edad Media (Valladolid, 1984); and María Bullón-Fernández (ed.), England and Iberia in the Middle Ages, 12th-15th Century: Cultural, Literary and Political Exchanges (New York, 2007).

${ }^{36}$ For example, in March 1298: "Commission to Philip de Hoyvill and John Randolf, to enquire touching the complaint by some burgesses of La Rochelle, of the power of the king of France, that whereas they had laded a ship called the ship of St. Mary of Castro Urdiales with 220 tuns of wine, to be taken to England by Peter de 
For intra-regional trade, Galicia sent grain and fish to the eastern Castilian seaports and imported salt from Cantabria and Asturias. The Basque Country shipped wool and iron to the seaports of Cantabria, Asturias and Galicia. Cantabria in turn sent manufactured iron products and wood to western Castilian seaports. ${ }^{37}$ In 1296, the eastern seaports formed a guild to protect and develop trade and for mutual aid and assistance. Called the Brotherhood of the Seafarers of Castile (La Hermandad de la Marisma de Castilla), it comprised seven seaports: Santander, Laredo, Castro Urdiales, Bermeo, Guetaria, San Sebastián and Fuenterrabía, and a town in the hinterland (Vitoria) ${ }^{38}$ The absence of a similar body in the western seaports speaks to their general weakness, which stemmed from a lack of royal favour, failure to establish complementary markets and competition from the Brotherhood.

\section{Consolidation of the Network: Town Councils and Port Infrastructure}

In the statutes (Las Partidas) of Alfonso X, "port" was defined as "a locked place in the mountains, or in the coast, where the ships can load or unload goods" and that provided shelter. ${ }^{39}$ As this definition suggests, the material reality of medieval ports could be breathtakingly simple; indeed, even the most highly developed ports lacked much in the way of infrastructure until the se-

Dyes, master of that ship, Peter de la Vygne and some men of Portesmuth took the ship with the wines and other goods in her at sea after the proclamation of the truce between the king and the king of France." Great Britain, National Archives (TNA/PRO), Calendar of Patent Rolls, 1307-1509, III, Edward II to Henry VII, 376. See also Childs, Anglo-Castilian Trade, 213-217; Wendy R. Childs, "Commercial Relations between the Basque Provinces and England in the Latter Middles Ages. ca. 1200-ca. 1500," Itsas Memoria, No. 4 (2003), 55-64; and Teófilo F. Ruiz, "Castilian Merchants in England, 1248-1350," in William C. Jordan, et al. (eds.), Order and Innovation in the Middle Ages: Essays in Honor of Joseph R. Strayer (Princeton, 1976), 173-185.

${ }^{37}$ Jesús A. Solórzano Telechea, "La producción y comercialización del hierro en las Cuatro Villas de la Costa de la Mar: aportación al estudio de la industria siderúrgica en la Corona de Castilla durante la Baja Edad Media," Studi Medievali (Spoleto) (2006), 71-110; Ferreira Priegue, Galicia: Elisa Ferreira Priegue, "Las rutas marítimas y comerciales del flanco ibérico, desde Galicia hasta Flandes," in El fuero de San Sebastián, 217-234; and Manuel González Jiménez and Isabel Montes Romero-Camacho, La Península Ibérica entre el Mediterráneo y el Atlántico. Siglos XIII-XV (Cádiz, 2006).

${ }^{38}$ Morales Belda, La Hermandad.

${ }^{39}$ José Sánchez Arcilla (ed.), Las Siete Partidas (Madrid, 2004). 
cond half of the fifteenth century ${ }^{40}$ Galician seaports were blessed with excellent natural shelter, thus reducing pressure to develop infrastructure. The typical port contained a beach or sandbank offering easy access for small craft and a nearby estuary with water sufficiently deep for ships to sit safely at anchor. Bridges were one of the most common and valuable forms of infrastructure in Galician ports. Cranes were sometimes positioned to facilitate cargo handling, and were used by workers to carry goods across them on foot. ${ }^{41}$ Galician ports featured stone wharves (peiraos), including one in the walled town of Pontevedra, which boasted a suburb (Moureira) inhabited by fishermen. ${ }^{42}$ Ships that could not come alongside the wharves stayed in the estuary. Pontevedra had a commercial wharf, the Peirao da Ponte, located inside the town, and a fishermen's wharf in Moureira, which handled only fish and fishery products. The Peirao da Ponte was built in 1339 because the town needed port facilities to avoid the dangers of low tide for ships. In 1491, the town council proposed a major overhaul, but it was not carried out until $1569 .{ }^{43}$ Until then, we know that the wharf was of free-stone construction. Curiously enough, local shipbuilding posed a unique challenge for wharf maintenance. Municipal ordinances reveal that the carpenters sometimes removed stones from the bridge to use as weights when submerging wood for warping. Afterward, they dumped the stones into the estuary. ${ }^{44}$ Financial responsibility for the construction and maintenance of wharves was widely paid for by alms, legacies, residents, merchants and municipal councils. Thus, when the Peirao da Pontevedra needed new steps in 1491, money for the project was donated by Gonzalo of Montenegro. And in 1497 the town council of Monterreal requested permission to charge anchorage fees to fund new wharf construction, something that other town councils had previously done. ${ }^{45}$

${ }^{40}$ Beatriz Arízaga Bolumburu and Jesús A. Solórzano Telechea, "La construction d'infrastructures portuaires dans les villes du nord de la péninsule Ibérique à la fin du Moyen Age," in Bochaca and Sarrazin (eds.), Ports et littoraux, 121-140. Cf. José Hinojosa Montalvo, "Ciudades portuarias y puertos sin ciudades a fines de la Edad Media en el Mediterráneo occidental," in Tecnología y sociedad: Las grandes obras públicas en la Europa Medieval (Pamplona, 1996), 263-287.

${ }^{41}$ Ferreira Priegue, Galicia, 120-124.

${ }^{42}$ Armas Castro, Pontevedra.

${ }^{43}$ Ferreira Priegue, Galicia, 121.

${ }^{44}$ García Oro, Galicia, 136.

${ }^{45}$ Archivo General de Simancas (AGS), Registro General del Sello, XIV, 258; and $1497,2$. 
Other infrastructure in Galicia, including shipyards and storage facilities, were scarce, and Corunna was the only port with a significant shipbuilding capacity. In 1505, Diego of Salamanca wrote that he had constructed "a very good and big ship of 700 tons in the port of Corunna, which has all the instruments, both for war and for peace." 46 The remaining Galician seaports had only small shipyards. The seaports also had warehouses for the long-term storage of fish, corn and salt. As one of the most fundamental aids to navigation, lighthouses were also an important piece of port infrastructure. Although lighthouses are rarely mentioned in the documentary record, evidence of their existence abounds in the toponymy of coastal areas. ${ }^{47}$

Except for the seaports of Avilés and Gijón, Asturias sorely lacked infrastructure until almost the sixteenth century, and most harbours consisted of little more than a pier. Ships anchored in deeper water, and small boats conveyed goods to the shore. Wharf construction seems to have begun only in the sixteenth century when the volume of trade increased. Only Avilés possessed infrastructure comparable to the Cantabrian and Basque towns. It boasted a bridge, called Los Pilares, and a small wharf which, however, could not accommodate large ships. When silting forced the closure of the wharf in 1488, the Catholic kings permitted the town council to charge a new tax on goods. ${ }^{48}$ Close to Avilés was Gijón, whose infrastructure was documented first in $1488 .{ }^{49}$ The remaining Asturian ports did not begin to build infrastructure until the early sixteenth century; even then, the results were disappointing. In 1511, Ribadesella decided to build a wharf, but otherwise there are no records of further improvements until mid-century. ${ }^{50}$ In 1550, a tax was introduced to pay for construction of a new wharf in Gijon, but the work was not finished until 1595. Similar projects took place in Lastres and Llanes. ${ }^{51}$

${ }^{46}$ García Oro, Galicia, 220.

${ }^{47}$ In 1217, the lighthouse of Corunna was documented in the Emonis Chronicle. See Jaime Ferreiro Alemparte, Arribadas de Normandos y Cruzados a las costas de la Península Ibérica (Madrid, 1999), 124.

${ }^{48}$ Eloy Benito Ruano, "Catálogo de pergaminos del archivo municipal de Avilés," Boletín del Instituto de Estudios asturianos, No. 86 (1975), 619-650.

${ }^{49}$ Covadonga Cienfuegos Alvarez, Libro de acuerdos del concejo de Avilés (1479-1492) (Oviedo, 1999), 151.

${ }^{50}$ AGS, Consejo Real de Castilla, 658, 4.

${ }^{51}$ Ignacio Adaro Ruiz, El puerto de Gijón y otros puertos asturianos (Gijón, 1976); and José I. Ruiz de la Peña, Las polas asturianas en la edad media (Oviedo, 1981). 
On the Cantabrian coast, natural conditions limited the potential for seaports, with only four bays able to accommodate shipping: Castro Urdiales, Laredo, Santander and San Vicente of Barquera. ${ }^{52}$ Even these were fairly open, but in all except Laredo, small hills offered reasonable protection from northwesterly winds. Only the most basic port facilities - small, timber wharves and not much else - existed before the mid-fifteenth century, and these were prone to be swept away during storms.

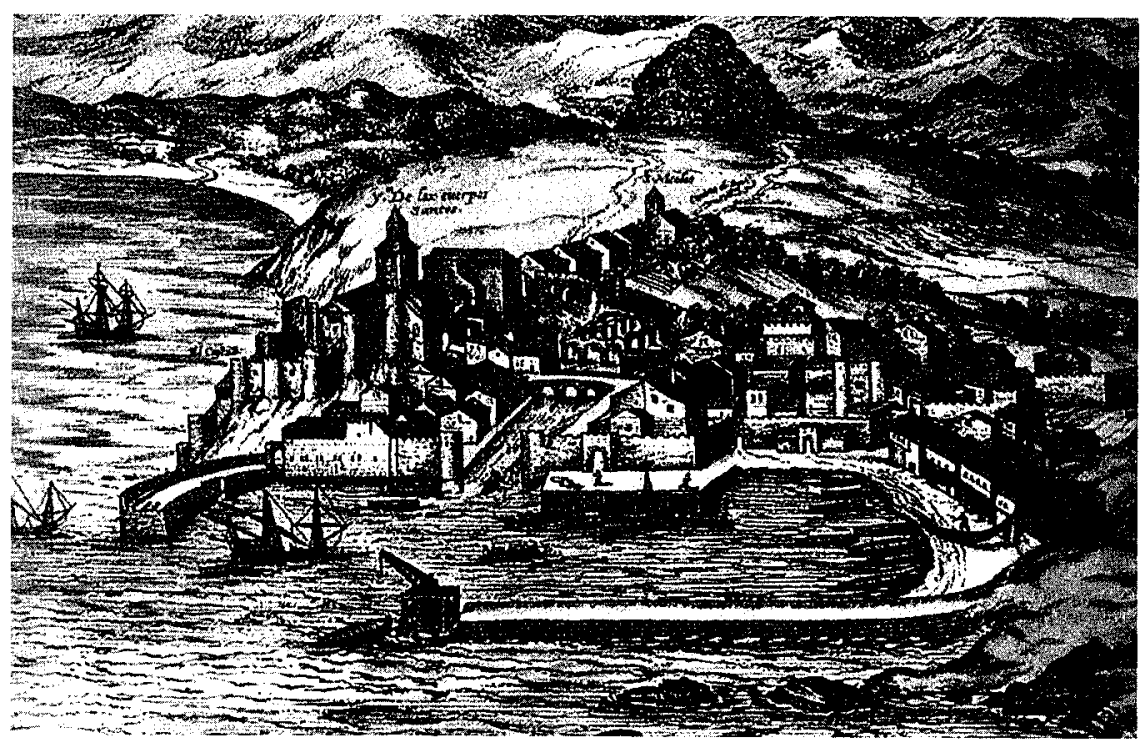

Figure 2: View of Santander, showing the port and harbour, ships in the bay and mountains beyond (c. 1565)

Source: Hand-coloured engraving by George Braun in collaboration with Frans Hogenberg in George Braun (ed.), Civitates Orbis terrarum (Cologne, 1575).

The most substantial wharf in medieval times was at Santander. Located inside the town walls, the wharf had an area of roughly 4000 square metres. It was near the mouth of the Becedo River, which divided the town into two parts. On each side of the harbour entrance (Boquerón) was a tower, and a chain between them restricted access to the urban centre. Construction of a dockyard on the shores of the Becedo estuary in the late fourteenth century forced small boats out of the area, in part to maintain a clear path for the ships

${ }^{52}$ Jesús A. Solórzano Telechea, "El fenómeno urbano medieval en Cantabria," in Solórzano Telechea and Arízaga Bolumburu (eds.), El fenómeno urbano medieval, 241-307; and Solórzano Telechea, “La fundación," 315-328. 
that were constructed there and to allow for the construction of a new wharf. Called the Coopers' Dock (Cay de los Toneleros), it appeared for the first time in 1428. Smaller wharves of timber construction were located outside the main port area; meanwhile, fishermen brought their boats ashore on a beach on the outskirts of town. In the southern section of the port lay the "Dock of the Vessels," first noted in 1434. Access to this dock, which was close to the castle and town walls, was through a gate. As in many other ports, larger ships could not draw near and thus had to anchor in the bay, relying on lighters to convey goods. All aspects of the port's infrastructure were in poor shape by 1504, but the town council did not consider replacement facilities until forty years later. When it did, it initially proposed a wharf 650 metres long, but in the end the wharf was only 250 metres. ${ }^{53}$ An engraving by George Braun shows the results of the major upgrade begun in 1561 (see figure 2).

The Dockyard (Atarazanas) was not only a fundamental part of Santander's port infrastructure but also the only one on the entire Cantabrian coast. First documented in 1391, it was destroyed by fire in 1425, then rebuilt. It, however, was short-lived, and according to municipal records it collapsed in 1504. The port's facilities included separate buildings for storing wheat and salt, and, from the start of the fifteenth century, the Bastida, an all-purpose store close to the town wall. In 1453, the council levied an annual tax on the Merchant Society of Burgos to cover the cost of repairs and maintenance. ${ }^{54}$

Santander's strength derived from three main sources: natural features, including its large bay, sandy beach and estuary; a central location on the coast; and easy access to a productive hinterland. In addition, its municipal leadership jealously guarded the town's interests. In the early fifteenth century, when the inland community of Santillana, controlled by the Mendoza family, wanted a coastal outlet, its town council established a port in San Martín de La Arena, just west of Santander; Santander's council defeated the threat by erecting its own facilities there. ${ }^{55}$ This was part of a process by which Santander created a network of regional satellite ports in the fifteenth century.

In Laredo, east of Santander, construction of port facilities began in 1448, chiefly to mitigate the impact of tidal flooding during storms. Progress

${ }^{53}$ Fernández González, Archivo de la catedral de Santander, docs. 158 and 212; and Jesús A. Solórzano Telechea and Lorena Fernández González, Conflictos jurisdiccionales entre la villa de Santander y el Marquesado de Santillana en el siglo XV (Santander, 1996), 157.

${ }^{54}$ Solórzano Telechea, Santander en la Edad Media, 94; Solórzano Telechea, Patrimonio documental de Santander, doc. 53; and Jesús A. Solórzano Telechea, Colección diplomática del Archivo Municipal de Santander: Documentación medieval (Santander, 1995), doc. 255.

${ }^{55}$ Solórzano Telechea and Fernández González, Conflictos, 30-78. 
was slow, and the work was suspended in 1460. That same year, however, Henry IV gave the council permission to erect a new wharf, but this project was interrupted in 1474 because of the plague and political unrest following his death. Determined to capture a share of the growing trade between Burgos and other Castilian cities and France, England and Flanders, the town council returned to the task in 1489. Five years later, stormy seas washed away the town's walls and flooded many houses, but the port facilities survived until 1523. Because the harbour was built primarily for the protection of the town it was not able to receive ships of great tonnage. In 1557, a traveller described the facilities as "walls in the sea for fortification of the land." When completed, Laredo's port infrastructure included storage facilities, notably the iron warehouse (alfoni del hierro), whose existence was first documented in 1398. The council was able to control the important traffic in iron by issuing licenses to ships using the port. ${ }^{56}$

Like Laredo, Castro Urdiales was highly exposed; in the absence of port facilities, its fishermen and sailors had to moor their craft in open water, not far from the town square. The town council initiated port construction in 1508 , explaining to Queen Juana I that "the town was destroyed annually by the sea." Construction was delayed because engineers miscalculated the cost, but the works lasted until 1528. Also like Laredo, Castro Urdiales's port facilities included an iron warehouse. ${ }^{57}$

San Vicente de la Barquera had an anchorage and wharf in the later Middle Ages. The former was situated close to the castle and was accessible from the northern gate. The customs office was located inside the castle. An old stone structure on the outskirts of town was the only wharf before 1500 . In the 1620 s, Pedro de Teixera recorded that the town had only a small wharf. ${ }^{58}$

${ }^{56}$ Archivo Histórico Provincial de Cantabria (AHPC), legajo 61-62; and legajo 10-3, fols. 23-24; AGS, Cámara Castilla, Memoriales, fols. 148-149; Registro General del Sello, XI, fol. 353; and XV, fols. 6 and 62; and Miguel A. Aramburu Zabala and Begoña Alonso Ruiz, Santander: un puerto del Renacimiento (Santander, 1994), 54.

${ }^{57}$ Beatriz Arízaga Bolumburu and José L. García (eds.), Castro Urdiales en la Edad Media: La imagen de la villa (Santander, 2001), 53; Beatriz Arízaga, "Castro Urdiales en la Edad Media: el espacio urbano," in Arízaga Bolumburu and García (eds.), Castro Urdiales y las Cuatro Villas de la costa de la mar en la historia (Santander, 2002), 65; Archivo Real Chancillería, Pleitos Civiles, Escribanía Masas, caja 3393/2, L2; and Gonzalo Martínez Díez, Libro Becerro de las Behetrías: Estudio y texto crítico (León, 1981), 570.

${ }^{58}$ AGS, Registro General del Sello, 28 May 1506; and Dámaso López García, Cinco siglos de viajes por Santander y Cantabria (Santander, 2000), 92. 
In Biscay there were seven seaports: Bilbao, Portugalete, Plencia, Bermeo, Lequeitio, Ondárroa and Motrico, of which only four possessed any real port infrastructure. The most important in the later Middle Ages was Bilbao, founded by Diego López de Haro V in 1300 in the Nervión estuary. Although a secure port, access was difficult. The first mention of wharves in Bilbao was in 1402, the same year in which we learn of San Antón's Bridge. During the first half of the fifteenth century the town had a small harbour, which was expensive to maintain because of flooding. In 1470, Enrique IV gave the council permission to charge a tax on the transport of goods, with revenues going to various repairs stemming from that year's flooding. Similarly, Isabel I gave Bilbao the privilege to receive royal revenues from wine and fish in order to acquire funds "to repair the wharves, walls and bridges." Between 1540 and 1542, the town council built a new wharf, but after the catastrophic floods of 1553 , work did not resume until $1560 .^{59}$

Bilbao's emergence as the most important port in the urban Atlantic network of northern Castile during the second half of the fifteenth century hindered the development of other Basque seaports. Bermeo began to build a wharf in 1489, for which its town council sought money from the Catholic kings. Instead of granting their request, the kings ordered the Royal Governor, Antonio Cornejo, to prepare detailed estimates and to explain why a wharf was necessary. Between 1500 and 1510 , a wharf was finally constructed, only to be destroyed by a storm in 1517. In Portugalete, a wharf was built between 1502 and 1514; the town also had an unknown number of dockyards. Lequeitio was the fourth and final town in Biscay with a port infrastructure. In 1463, the town council used tax revenues to fund new work, which was quite expensive. In 1468, the council used tax revenues to pay Ochoa Sánchez de Mendiola for getting on with the works. ${ }^{60}$

${ }^{59}$ Javier Enríquez Fernández, et al., Colección documental del Archivo Histórico de Bilbao (1300-1473) (San Sebastián, 1999), docs. 1, 98 and 159; Sergio Martínez Martínez, "Desarrollo urbano de Bilbao en la Edad Media," in Arízaga Bolumburu and Solórzano Telechea (eds.), Ciudades y Villas portuarias, 115-145; Bilbao, arte e historia, Vol. I (Bilbao, 1990) 42; and Sergio Martínez Martínez, "Bilbao: nacimiento de un emporio," Litoral Atlántico. Villas al mar. Ciudades medievales, I (Santander, 2001), 70-80.

${ }^{60}$ AGS, Registro General del Sello, fols. 12 and 153; Archivo de la Real Chancillería de Valladolid, Reales Ejecutorias, caja 361/51; Enríquez Fernández, et al., Colección documental, doc. 3; María Rosa Ayerbe Iribar, et al., Colección documental del Archivo Municipal de Portugalete (San Sebastián, 1987), docs. 15 and 56; and Javier Enríquez Fernández, et al., Colección documental del Archivo Municipal de Lequeitio, Vol. I (1325-1474) (San Sebastián, 1992), 165; and Vol. III (1496-1513), 616. 
In the province of Guipúzcoa, adjacent to France, there were eight seaports (Deva, Zumaya, Guetaria, Zarauz, Orio, Fuenterrabía, Rentería and San Sebastián), but only five of them had any infrastructure. The most important was San Sebastián, which, despite a good bay and impressive natural protection offered by the Island of Santa Clara and Mount Urgull, could not be used by large ships owing to the water's shallow depth. To remedy this, the town council started to build a wharf in 1440, for which they approached the king for funds. In 1463, after Enrique IV gave them money they erected a wharf parallel to Mount Urgull. In 1522, this wharf was extended; according to a source from 1552 , it could accommodate more than seventy ships. ${ }^{61}$

Located on a peninsula, Guetaria was protected by the Island of San Antón. It did not have a wharf until the late fifteenth century; until then, the main anchorage was off the beach. After the Island of San Antón and Guetaria were linked, this beach disappeared. Construction of a wharf on the Island of San Antón began in 1479 but was not completed until $1541 .{ }^{62}$ Motrico had the oldest port infrastructure of any eastern seaport, boasting two small wharves in the mid-thirteenth century. Both were enlarged in the sixteenth century to accommodate bigger ships. ${ }^{63}$ Rentería had some port infrastructure close to Oyarzun River. In 1495, the town asked the kings for funds to repair an old wharf. Their request seems to have been granted, for the wharf was fixed two years later. ${ }^{64}$

\section{Conclusions}

Access to the sea was the dominant factor in the economic development of all of Spain's northern Atlantic seaports. In addition to serving as a food source, the sea created employment for merchants, fishermen, mariners and affiliated tradesmen. In this context, the creation of port infrastructure was an integral part of urban expansion. In 1542, when the Santander town council requested money from the local church, the councillors asserted that the wharf "would

${ }^{61}$ Lorena Fernández González, "El fenómeno urbano medieval en el territorio guipuzcoano: aspectos fundamentales sobre su origen y desarrollo," in Solórzano Telechea and Arízaga Bolumburu (eds.), El fenómeno urbano medieval, 110-174; Beatriz Arízaga Bolumburu and Lorena Fernández González, "San Sebastián-Donosti: Villa portuaria y atlántica en la Edad Media," in Litoral Atlántico. Villas al mar: Ciudades medievales (Santander, 2001) 54-68; and Public Archive of Lequeitio, fondo histórico, registro 16, no. 14 .

${ }^{62}$ AGS, Registro General del Sello, volume II, fol. 63.

${ }^{63}$ Fernández González, “El fenómeno urbano medieval,” 121.

${ }^{64}$ AGS, Registro General del Sello, XII, fol. 167. 
increase population, enlarging the congregation to pay tithes, directly benefiting the church." ${ }^{65}$ The urban elites used port infrastructure as an instrument of power. Wharves offered protection from floods, storms and invasions, and this security acted as a further stimulus to economic and demographic growth. For example, port work in Laredo in 1448 was seen as a way both to counter floods and to strengthen the town's defences. In other words, the benefits of port development were numerous and widespread. Thus, applications by municipal governments for financial assistance for infrastructure projects typically included wording to the effect that the work would be for the "common good." ${ }^{66}$ This is not to suggest that self-interest did not play a role; by advancing projects that served the interests of the community at large, councillors ensured that their own power would be maintained.

The geography of Spain's northern Atlantic coast was not especially conducive to the development of port cities and urban networks. Nonetheless, the seaports overcame physical limitations to become part of an urban network. This network embodied a complex web of regional and international connections based on the movement of people and goods and the related exchange of information (communications). Traditionally, historians have assigned excessive importance to the influence of geography and communications on the development of urban networks. In medieval Atlantic Spain, port infrastructure was slower to emerge than in other parts of western Europe; as a consequence, royal support and personal relationships among sailors and merchants exercised a greater role in the creation of networks.

The construction of port infrastructure helped to advance royal aims for the region. In particular, the seaports established the material and logistical bases for commercial ties between Castile and France, England, Ireland, Flanders and northern Europe. Be that as it may, the Basque and Cantabrian town councils were key protagonists in the struggle for port infrastructure. Of the fifty seaports founded between the twelfth and fourteenth centuries, the eastern ones stood out in their more extensive development of infrastructure, especially in wharf construction. The pressure to develop infrastructure was greater in the east (Cantabria and the Basque Country), in part because natural conditions were more favourable in the west (from Galicia to the Portuguese border) where the local economies were dominated by fishing. The eastern ports blended fishing with trade, thus necessitating infrastructure, especially docks,

\footnotetext{
${ }^{65}$ Public Archive of Santander, Leg. B izdo. 306, S.F. (mid-sixteenth century), no. 32 .

${ }^{66}$ Elisabeth Crouzet-Pavan, "'Pour le bien commun...:' A propos des politiques urbaines dans l'Italie communale," in Pouvoir et édilité: Les grands chantiers dans l'Italie communale et seigneuriale (Rome, 2003), 11-40; and José Manuel Nieto Soria, "Fragmentos de ideología política urbana en la Castilla Bajomedieval," Anales de la Universidad de Alicante. Historia Medieval, No. 13 (2000-2002), 203-229.
} 
better suited to larger ships. There were of course docks in Galicia and Asturia, but in nowhere near the same profusion as in the east. 